\title{
Group A Streptococcal Infection - Biochemical and Pharmacological Aspects
}

\begin{abstract}
RAMONA MIHAELA NEDELCUTA', VLAD DUMITRU BALEANU2*, DRAGOS VIRGIL DAVITOIU³, TIBERIU STEFANITA TENEA COJ AN ${ }^{4}$, ANCA PASCAL ${ }^{5}$, BOGDAN SOCEA ${ }^{6}$, COSMIN ALEXANDRU CIORA ${ }^{7}$, GIGI CALIN ${ }^{1}$ 'University of Medicine and Pharmacy of Craiova, Pediatrics Department, 2 Petru Rares Str., 200349, Craiova, Romania 2University of Medicine and Pharmacy of Craiova, Surgery Department, Clinical Emergency Hospital St. Pantelimon, 340-342 Pantelimon Road, 021659, Bucharest, Romania

${ }^{3}$ University of Medicine and Pharmacy of Bucharest, Surgery Department, Clinical Emergency Hospital Sf. Pantelimon, 340-342 Pantelimon Road, 021659, Bucharest, Romania

4University of Medicine and Pharmacy of Craiova, Department of Surgery, CFR Hospital, Stirbei-Voda Str., 200374,Craiova, Romania

${ }^{5}$ Department of Anesthesiology and Intensive Care, Universitary Emergency Hospital Bucharest, 169 Splaiul Indepenei, 050098, Bucharest, Romania

${ }^{6}$ Sf. Pantelimon Emergency Clinical Hospital, 340-342 Pantelimon Road, 021659, Bucharest, Romania

${ }^{7}$ Carol Davila University of Medicine and Pharmacy, Discipline of Gastroenterology and Hepatology, 8 Eroii Revolutiei Blvd., 050474, Bucharest, Romania

The medicine of the last years is evidence-based - most of the theoretical information that has occurred in the past 10 years is already out of date. The Axioma of Classical Pediatrics - Any Group A Haemolytic Beta Streptococcus must be treated with Penicillin $G$ is no longer relevant The results of a study at the Hospital Philanthropy from Craiova are not at all surprising, overlapped with those found in medical practice.Age entails moving the diagnosis to the baby, sensitivity to penicillin occurs in only $1 / 4$ of children, microbial resistance to the antibiotic is common in many antibiotics.
\end{abstract}

Keywords: streptococcus, children, antibiotics

Streptococcus hemolytic beta-Streptococcus $A$ is a round oval gram positive coccus, disposed in pairs of chains, immobile, optionally anaerobic, catalase-negative, nonspore-forming. Some strains are encapsulated, the capsule being a marker of virulence.

Blood haemolysis by PYR assay identifies pyrrolidonyl amidase synthesis; Group A streptococcal proliferation is inhibited by bacitracin; based on carbohydrate composition of bacterial antigens (Lancerfield) group B hemolytic group $A$, streptolysins causing hemolysis; in the wall there is $M$ protein with antiphagocytic role.

It contains extracellular enzymes and toxins: streptolysin $0, S$, PSE (pyrogen streptococcal exotoxins) type A, B, C, which produces scarlatin, exanthema, enanthem, septic shock; superantigens, streptokinases, hyaluronidases [1].

Group and beta-hemolytic streptococcus infection affects $30-40 \%$ of children with pharyngitis $[2,3]$.

The source of infection is the sick man or the asymptomatic chronic pharyngeal carriers, through Pflügge drops or direct contact because the bacteria does not resist the external environment.

\section{Experimental part}

Methods and materials

Streptococcal pathology is extremely varied: pharyngitis, scarlet fever, impetigo, erizipel, cellulitis, necrotizing fasciitis, angina, rhinitis, sinusitis, meningitis, malignant endocarditis, toxico-septic syndrome[ 4,5].

The most serious complication: rheumatic fever, carditis, glomerulonephritis.

The most common diagnosis is acute pharyngitis, supported by anamnesis, clinical examination, laboratory test, bacteriological test (which states the etiology) [610].
Bacteriological test

Tests to confirm bacterial infection:

-bacitracin test,

-latex agglutination test

-coaglutinations ELISA,

-blood agar culture (hemolysis, S, A colonies),

-Quellung reaction,

-PYR test

-ASLO for streptococcus pyogenes, antibody tests for other antigens (streptokinase, hyaluronidase, anticarbohydrate) [11-13].

There are classical axioms. Are they up to date? The results speak for themselves:

-The drug of chose is penicillin G or V and, in those allergic to erythromycin or oxacillin.

-No antibiotic for group A haemolytic beta streptococcus is performed.

-The infection particularly affects children over 3 years, not infants $[14,15]$.

History: Penicillin's microbial resistance began with the invention of Penicillin in 1928 by Alexander Fleming, which represented a big step in microbial therapy.

The explanation was given in 1885 by Victor Babes, who observed the inhibitory action of substances elaborate by microorganisms.

In 1930, the first cases of Penicillin microbial resistance were already observed [16].

We selected a group of 174 patients by group A haemolytic beta-streptococcal confirmed by exudate from a total of 1273 hospitalized children over a whole year.

Cold months confirm the incidence of bacterial infection.

Findings were stratified by age group: 14 - infants, 10 between 1-3 years, 24 over 7 years, between 3-7 years 126 cases. 51 antibiograms were performed. 

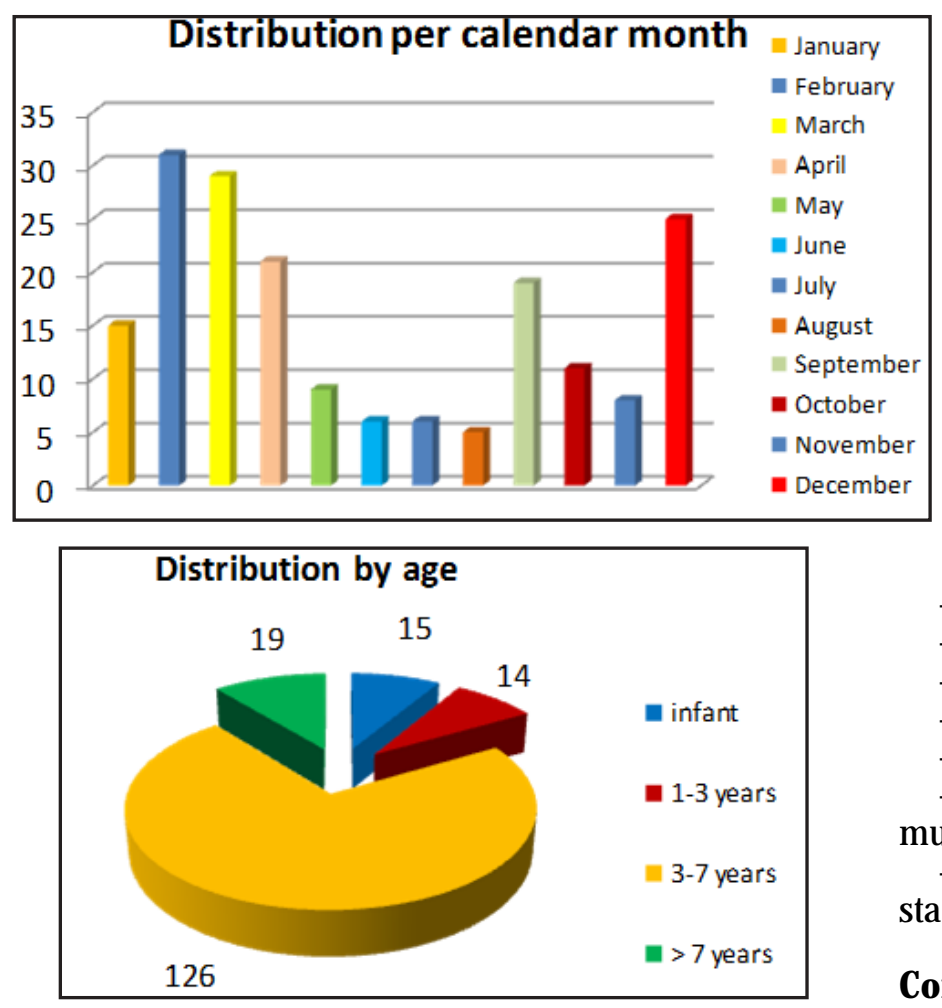

Fig 2. Age stratification

\section{Results and discussions}

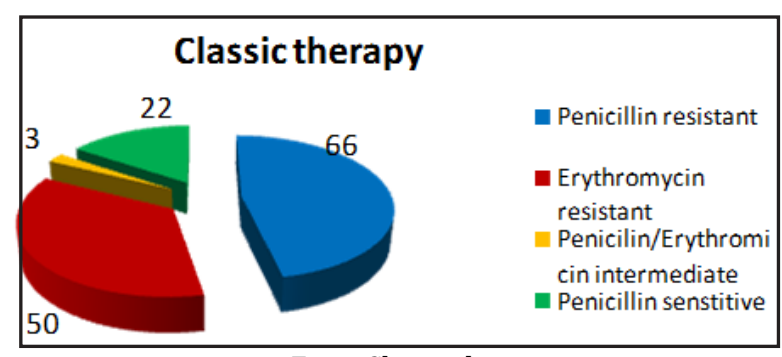

Fig 3. Classic therapy

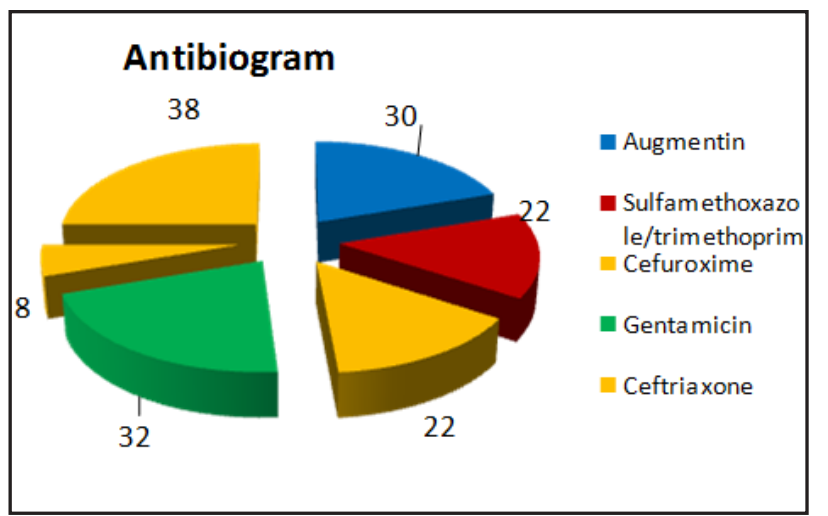

Fig 4. The results of antibiogram

Most bacteria have proven resistantto classical therapy with Penicillin or Erythromycin.

Some explanations for the occurrence of the disease at infancy may be:

-Close intimate intra-family contact

-Predigestion of food under the action of salivary amylase from the mother, still practiced in our country

-Insufficient sterilization of the teat, pacifier, as well as wetting it before it is given to the baby [17-21].

Possible explanations and theories:
Fig 1. Bacterial infections distribution per calendar month

- internalization in the tonsillar crypt; -different response in vivo - in vitro; -abuse of antibiotics at younger age; -the local floral defenses destroyed;

-multiple hospital admission for other affections;

-alginate theory, possibly as in pseudomonas defense in mucoviscidosis;

-double etiology of angina - streptococcus and staphylococcus [22,23].

\section{Conclusions}

The future is evidence-based medicine where YES and NOT are relative, not absolute.

Axioms become theorems that will need to be demonstrated; otherwise the proof of the time drops.

Polypragmasia forces accelerated entry into a new age, where new bactericidal drugs with a very wide spectrum will be invented, in which the microbiota will have to be strengthened and blossomed where immune barriers will need to be stimulated efficiently and quickly.

There is no disease but the patient is a dictum of old pediatrics strengthens by the present times

The well-known semiological picture changes rapidly for various illnesses and the tendency of establishing protocols is increasing.

The antibiotic should be a mandatory step to indicate the sensitivity of any germ.

Questions remain to be answered:

The benefit could be for the doctor, protected by the protocol, but what about complicated affections?

How do we effectively combine different protocols?

Can the protocol be assimilated to an axiom but do their axioms have their place in pediatrics?

\section{References}

1.PATRICK R. MURRAY, PHD, KEN S. ROSENTHAL, PHD AND MICHAEL A. PFALLER, MD: Medical Microbiology, 7th Edition, Elsevier Health Sciences, 2012; ISBN: 978-0-323-08692-9

2.SHAIKH N, et al. Prevalence of streptococcal pharyngitis and streptococcal carriage in children: A metaanalysis. Pediatrics 2010;126:e557-e564.

3.CARAPETIS JR, et al. The global burden of group A streptococcal diseases. Lancet Infect Dis 2005;5:685-694.

4.CHOBY BA. Diagnosis and treatment of streptococcal pharyngitis. Am Fam Physician 2009;79:383-390.

5.AMIEVA-WANG NE, et al eds. A Practical Guide to Pediatric Emergency Medicine: Caring for Children in the Emergency Department. New York: Cambridge University Press; 2011.

6.STEVENSDL, KAPLAN EL. Streptococcal Infections: Clinical Aspects, Microbiology, and Molecular Pathogenesis. New York: Oxford University Press; 2000.

7.STEER AC, et al. Invasive group A streptococcal disease. Drugs 2012;72:1213-1227. 
8.CLENCIU, D., TENEA COJAN, T.S., DIJ MARESCU, A.L., ENE, C.G., DAVITOIU, D.V., BALEANU, V.D., CIORA, C.A., SOCEA, B., VOICULESCU, D.I., NEDELCUTA R.M., CALBOREAN, V., GHEORMAN, V., VLADU,I.M., Rev.Chim. (Bucharest), 70, no.4, 2019, p. 1434-1438.

9.NEDELCUTA, R., BALEANU, V.D., CIORA, C., CALIN, G., STANESCU, M.R., DAVITOIU, D.V.. TENEA COJAN, T.S., SOCEA, B., VOICULESCU, D.I., ALEXANDRU, D.O., STANESCU, R, Rev. Chim. (Bucharest), 70, no.5, 2019, p. 1859-1862.

10.GHEORMAN, V., DINESCU, V.C., CRICIOTOIU, O., STANCA, D., CALBOREAN, V., MITA, A., MISCOCI, A., DAVITOIU, D.V., BALEANU, V.D., NEDELCUTA, R.M., DINESCU, S.N., DIJ MARESCU, A.L, VOICULESCU, D.I., UDRISTOIU, I., Rev. Chim. (Bucharest), 70, no. 4, 2019, p. 1406-1410.

11.MARTIN J M, et al. Group A streptococci among school-aged children: Clinical characteristics and the carrier state. Pediatrics 2004;114:1212-1219.

12.W ONG SS, YUEN K-Y. Streptococcus pyogenes and re-emergence of scarlet fever as a public health problem. Emerg Microbes Infect 2012;1:e2.

13.SHULMAN ST, et al. Clinical practice guideline for the diagnosis and management of group A streptococcal pharyngitis: 2012 update by the Infectious Diseases Society of America. Clin Infect Dis 2012;55:e86-e102.

14.WOODS WA, et al. Detection of group A streptococci in children under 3 years of age with pharyngitis. Pediatr Emerg Care 1999;15:338340.

15.SHULMAN ST, TANZ RR. Group A streptococcal pharyngitis and immune-mediated complications:From diagnosis to management. Expert Rev Anti Infect Ther 2010;8:137-150.
16.FLEMING A. On the antibacterial action of cultures of a Penicillium with special reference to their use in the isolation of $\mathrm{B}$. influenza. $\mathrm{Br}$ J Exp Pathol. 1929;10:226-36.

17.GEREIGE R, SAUTU B. Throat infections. Pediatr Rev 2011;32:459469.

18.NEDELCUTA, R, POPESCU, M, CALIN, G. Digestive Manifestations in Wilms' Tumor. NEUROGASTRO 2017 - MEETING OF THE ROMANIAN SOCIETY OF NEUROGASTROENTEROLOGY WITH ROME IV REGIONAL CENTRAL EAST EUROPEAN MEETING. 2017, p. 200-204.

19.STANESCU, GL, NEDELCUTA, RM, DOP, D, DIACONU, R, CALIN, G, NICULESCU, EC, GHEONEA, C, STANESCU, R, ANGHELINA, L, STANESCU, MR. Brain abscess of unknown etiology in a 2-year-old child: a case report. Rom J Morphol Embryol 2015, 56(3). p. 12011204.

20.NEDELCUTA, R.M., CALIN, G., BALEANU, V.D., DAVITOIU, D.V., VOICULESCU, D.I., MIREA, C.S., TENEA COJAN, T.S., SOCEA, B., ALEXANDRU, D.O., CLENCIU, D., GHEORMAN, V., UDRISTOIU, I., CALBOREAN, V., CIORA, CA. Rev. Chim. (Bucharest), 70, no. 5, 2019, p. 1698-1702.

21. ${ }^{* * *}$ American Academy of Pediatrics Committee on Infectious Diseases. Pickering LK, ed. Red Book 2012 Report of the Committee on Infectious Diseases. 29th ed. 2012.

22.VAN DRIEL ML, et al. Different antibiotic treatments for group A streptococcal pharyngitis. Cochrane Database Syst Rev 2013;4:CD004406.

23.RANDOLPH MF, et al. Effect of antibiotic therapy on the clinical course of streptococcal pharyngitis. J Pediatr 1985;106:870-875.

Manuscript received: 4.11 .2019 
